\title{
ECONOMICS
}

\section{The economy in Ukraine: the essence, causes, ways of solving}

\author{
L. Vodianka ${ }^{1}$, N. Stakhova ${ }^{2}$, L. Sybyrka ${ }^{3}$ \\ ${ }^{1}$ Department of Economics of Enterprise and Personnel Management, Chernivtsi National University named after Y. Fedkovych, Chernivtsi \\ ${ }^{2}$ Department of Finance of the Secondary School of Economics "Bukovyna University", Chernivtsi \\ ${ }^{3}$ Department of Economics of Enterprise and Personnel Management, Chernivtsi National University named after Y. Fedkovych, Chernivtsi \\ Corresponding author.E-mail: 1.vodjanka@chnu.edu.ua, nataliastahova@ukr.net, sybyrushka@gmail.com
}

Paper received 28.05.19; Accepted for publication 10.06.19.

\section{https://doi.org/10.31174/SEND-HS2019-199VII33-01}

\begin{abstract}
The history of the shadow economy, its separate features begin with the emergence of the state. In the XX century, for countries experiencing a systemic crisis, the problems of the shadow economy became very important. Since the 70s, this topic has become popular in Western economists, and since the 1980s it has become popular in the Soviet Union. This interest was due to the growth of the shadow economy, its penetration into all spheres of economic and social relations in almost all countries of the world, as well as the fact that the spread of the shadow economy today constitutes a threat to national security. However, the quantitative and qualitative parameters of the shadow economy vary greatly depending on the specific economic, social, historical and cultural peculiarities of one or another country. The problem of the existence of the shadow economy in Ukraine is of particular relevance today in connection with the election of a European vector of development by the Ukrainian society. Achieving the goal of Ukraine's accession to the European Union is only possible if the shadow economy is reduced, and its level in the developed countries is much lower than in our country, due to the greater trust of the citizens of such countries in state institutions. A significant turnover of shadow capital destroys the system of economic relations in the country, the withdrawal of these capital from the "shadow" and is the main way to improve the domestic economy. In this article the essence of the concept of the shadow economy, its influence on the development of the Ukrainian economy is disclosed. The main reasons that hinder the process of the Ukrainian economy's exit from the shadow are explored, as well as a number of measures that will promote de-shadowing.
\end{abstract}

Key words: the shadow economy, the level of the shadow economy, the causes of the shadow economy, the effects of the shadow economy, shadowing of the economy.

Formulation of the problem. The shadow economy is an important macroeconomic indicator of any state. To date, there is no country that would completely lose sight of the shadow sector. The presence and expansion of shadowing of the economy impedes socio-economic reforms of the state and distorts indicators of economic development, in particular GDP. Therefore, the coexistence of shadow economic activity with the legal one leads to a significant reduction in the share of tax revenues in the total amount of all budget revenues, which in turn leads to a reduction of public expenditures that should be directed towards the development of various spheres of human activity. It should be noted that the shadow sector not only paralyzes and distorts the state's economy, but also disturbs the balance in society.

Therefore, the relevance of studying the causes of the unshadowing of the economy is unquestionable. Only a detailed analysis of the reasons for the existence of the shadow economy will justify the main ways of solving this problem and prevent a negative impact on the development of the Ukrainian economy.

An analysis of the latest sources of research and publications. The hidden side of the economy has always attracted a large number of scholars. And it is not surprising, since the volumes of informal activity of enterprises grow year by year as quickly as their "gray" profits.

Among the works of domestic economists devoted to the problems of the shadow economy, the most significant are the study of P. Pernikoz, who studied the causes of significant amounts of the shadow economy and the ways of their elimination [1], O. Pilipchenko, who showed measurement methods and factors of negative impact on economic security [2], G. Yurchik, who showed the main di- rections of state policy in the field of shadowing of the national economy [3] and others. Among foreign scientists who are studying this problem, it should be noted scientist F. Schneider, who described the main causes of the destruction of the shadow economy [4].

Having read the publications of the above and other scientists, one can conclude that each author sees in his own way the solution of this problem, based on his own views, resulting in disputes and differences that require further research.

Setting objectives. The purpose of this article is to study the main causes of the formation of the so-called "shadow gap" in the economy and ways to overcome it. And also to analyze tendencies and peculiarities of the development of the shadow economy, to estimate its scale to date in comparison with other years.

The main research material. The impact of the shadow economy today is hard to miss, because it is closely interlinked with the legal sector of the economy. Unfortunately, today we have a rather sad picture, which shows that every year its influence grows at a rapid pace, which impedes the effective development of the legal sector of the economy. Therefore, we need to understand that this situation affects each of us as long as the main preconditions for its emergence are not explored, the positive and negative sides of it will not be clearly described, and the main ways of overcoming and prospects for the development of the state's economy, this unresolved, for the first look, the problem will always work as a brake system in our mechanism.

There are many reasons for the emergence and spread of the shadow economy.

It is necessary to focus on the main ones, which can be formed into several groups according to the fields of manifestation: 
- economic (high tax burden, inefficient economic management system, economic instability, excessive regulation of economic activity, etc.);

- legal (imperfection and constant changes of the legal basis, differentiation of the population in compliance with the rules of law, etc.);

- political (political instability, "weathervane power", etc.);

- social (bundle of society, drop in the level and quality of education, decrease in incomes, etc.) [5, p.28].

Let's consider each group in details.

Economic causes are one of the most important factors that influence and at the same time form the shadow sector of the state. Among them I would like to highlight a high level of tax burden. And not surprisingly, according to World Bank estimates, the tax system in Ukraine is the most complicated in the world. By simplicity of the procedure of payment of taxes, our state occupies $181^{\text {st }}$ place among 183 countries studied by experts of the World Bank, and by the number of taxes and fees, Ukraine occupies the $181^{\text {st }}$ place among 183 countries. It means that entrepreneurs need to spend 657 hours a year to pay all taxes. (Table 1).

Table 1. The complexity of paying taxes in different countries around the world

\begin{tabular}{|l|c|c|}
\hline Country & $\begin{array}{c}\text { Number of taxes } \\
\text { and fees (general } \\
\text { and local) }\end{array}$ & $\begin{array}{c}\text { Time spent on } \\
\text { their payment } \\
\text { (hours per year) }\end{array}$ \\
\hline Hong Kong & 3 & 80 \\
\hline Norway & 4 & 87 \\
\hline Georgia & 5 & 100 \\
\hline China & 7 & 398 \\
\hline Denmark & 9 & 135 \\
\hline Kazakhstan & 9 & 271 \\
\hline Russia & 11 & 320 \\
\hline USA & 11 & 187 \\
\hline Italy & 15 & 285 \\
\hline Ukraine & 73 & 657 \\
\hline
\end{tabular}

Source: World Bank (World Bank Group) [6]

According to the audit company PwS 2015, Ukraine ranks 23 rd place in the rating system dedicated to taxation. It is known that the total tax burden is 53\% [14]. With the help of the obtained indicators and the Laffer Curve, we can conclude that at a tax rate of $40-50 \%$, the business begins to go into the shadow through a decrease in motivation.

Today, the Ukrainian tax system is in a loop, the essence of which is as follows: the reduction of payments to the budget provokes a rise in tax burden, which causes a gradual increase in tax crimes.

For many years, our state has headed the ranking of European countries with the lowest wages. On average, Ukrainians received a payout of 190 euros in 2017, while in Switzerland - 4,421 euros [7]. Therefore, most Ukrainians do not want to work because they are well aware that they will not even be able to pay for utilities for the money they receive.

The entrepreneurs of "gray profits" are looking for workers who would have agreed to work for "salary in an envelope". They set their price list, which is bigger than state promises. For an employer, such employees are beneficial because they do not need to pay taxes, report, be li- able and pay compensation in case of unforeseen situations. As a result, for two thirds of the able-bodied population, revenues from the informal and unregistered economy have become a source of survival, offsetting the losses that it would have suffered in the formal economy.

Thus, due to revenues from shadow activity in total incomes of the population, a large share is occupied not by primary incomes, but by incomes derived from them and created in the sphere of distribution and redistribution. Such revenues are distinguished by the fact that they are separated at the local rather than at the social level, do not participate in the creation of the budget, the production of public goods, etc. This situation with distribution and redistribution leads to significant distortion of macroeconomic indicators (GDP, etc.), the creation of imbalances and the accumulation of contradictions. All this essentially affects the nature of social reproduction.

Economic reasons also include an inefficient system of managing the economy. After the collapse of the USSR, the economy of Ukraine experienced a number of significant transformations that were conducted without proper economic justification and with criminal negligence. During the period of structural reforms, some officials, instead of building a new market economy, were engaged in the sale of natural resources, the construction of financial pyramids, the capture of a large proportion of land and production resources, covered by the name of the state. But negligence on the part of the state leads to chaos in society, weakens economic and political activity, and thus enables the development of the shadow economy. Our government needs to change this situation, take an example from neighboring states, and choose "right leaders" for the people.

Another important reason for the formation of the shadow economy is imperfection and constant changes in the legal framework. Unfortunately, most entrepreneurs who would like to open their own business can't do this because of the complexity of the legislation. But even fewer people can stay in the real sector of the economy. Therefore, it is not surprising that small and medium business in our country occupies only $7 \%$. This indicates insolvency and insufficiency of steps taken by the state in order to strengthen the country's financial and economic system, improve macroeconomic indicators and ensure the proper development of society in comparison with other countries of the world.

To date, most of the leading countries in the world have made every effort and have made changes to the legislation in order to arrange and open their own business was easy and simple. For example, in Singapore you can obtain a license in two weeks or two months - depending on the type of business activity. And in Ukraine it takes twice as much time. Therefore, public administration bodies need to work in the legal sphere in order to correct their own mistakes and make appropriate decisions.

In addition to the economic and political factors that influence the prosperity of the shadow economy, social ones should also be noted. Today, it is not surprising to anyone that social differentiation is present in Ukraine, as in other European countries. A distinctive feature of stratification is the difference in incomes. As a result, in the shadow economy, representatives of the poor are used as a workforce (their share is $60 \%$ of the total). It should be noted that in 
recent years, there have been positive changes in the country, if in $2017,60 \%$ of the population lived below the poverty line, then by 2018 their share decreased by $20 \%$. According to the calculations of the Ministry of Economic Development, the level of the shadow economy for 2017 was $31 \%$ of the official GDP, which is $4 \%$ less than in 2016.

Every year the level and quality of education falls and shows us disappointing forecasts. The educational level of the population is the main source of nutrition for the informal sector. Because the low-educated population forms the bulk of the employed in the shadow economy. In addition, one should pay attention to the fact that the "main engine" that launches the "gray system" is highly skilled specialists. This situation arises as a result of the fact that the population with a high educational level becomes simply unclaimed on the official labor market. Therefore, many professionals are forced to direct their educational potential into the shadow sector, where the demand for them always exceeds the supply.

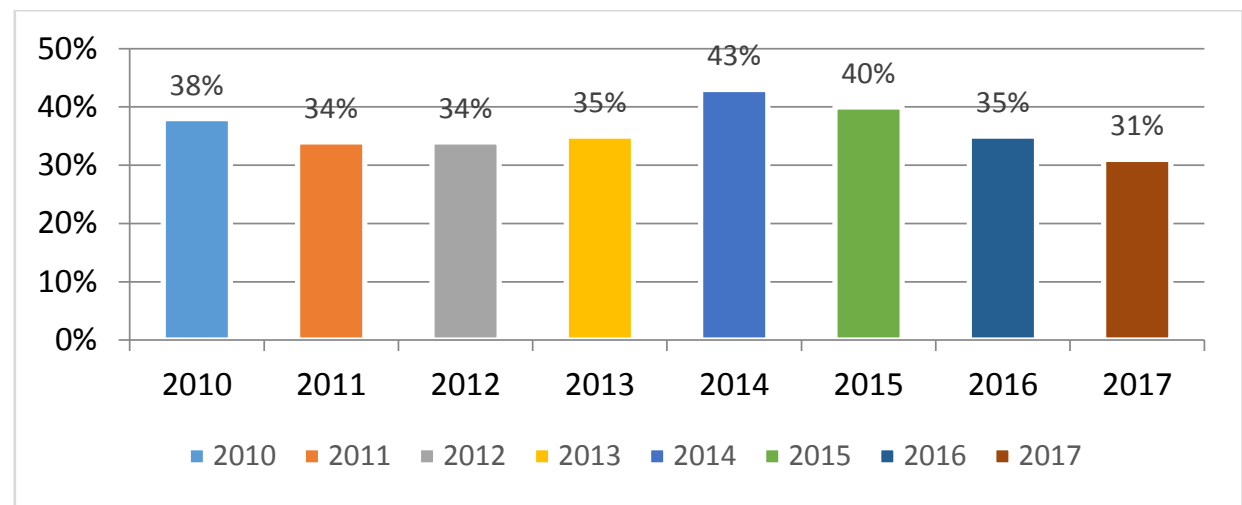

Fig. 1. The level of the shadow economy from official GDP, $\%$ for 2010-2017 Source: Ministry of Economic Development and Trade of Ukraine [8].

Political reasons that affect the growth of a hidden economy in the country are inseparable from economic reasons. After all, economics and politics are interrelated parts of one mechanism. It should be noted that political instability in our state has been present for a long time. In recent years, many managers have changed, but there is no desired result. Each successive official sees in his own way the solution to one or another problem, and therefore there is no clear plan of action in which direction one needs to move and develop. As a result, nobody wants to work, everyone tries to enrich only his pocket and maximize his profit by taking advantage of his position.

Conclusion. After analyzing the main factors of the formation of the shadow economy, one can confidently state that its influence on the macroeconomic system poses a potential threat to the national security of the state [9, p.41].

Every year the government tries to find ways to overcome this problem, but it will not be able to implement the reform movement that would ensure the economic and political development of our state. Therefore, it is possible to rely on positive changes only if the reasons causing shadow activity and implementation of the interconnected set of measures to improve the system of taxation and corporate governance, improvement of the structure of settlements and other indirect measures to improve the situation in the country are eliminated.

From the above, it is expedient to draw the following conclusions:

1) The main urgent reform of the current government should be the adoption of a law to reduce the rate of personal income tax (PIT) from $18 \%$ to $10 \%$ and the single social contribution (ECV) from $22 \%$ to $15 \%$, which will immediately increase the wages of people for several hundreds of hryvnia even at a minimum wage.

2) The replacement of the income tax with the tax on the withdrawn capital will allow for extensive modernization of production and the return of offshore. Reducing tax pressure will stimulate production efficiency, bring the economy out of the shadows and revive demand.

3 ) If VAT is reduced by $6 \%$, it will make Ukrainian goods cheaper and more affordable than imported goods. Domestic products will become more competitive, this will increase production, compensating for temporary losses from lowering tax rates.

4) Establishing appropriate authorities that would investigate the shadow sector, its impact on the macroeconomic level and trends over a certain period of time.

5) Creation of a favorable investment climate for foreign investors in order to attract and expand financial resources.

6) Adoption of a package of legislative acts, which should ensure the civilized functioning of the banking system of the country, limit the possibility of its use in order to avoid tax payments $[10$, p.53; 11,12,13].

7) Creating decent working conditions for highly skilled workers and providing appropriate wages to ensure a decent standard of living.

8) Focusing on law-enforcement structures on the elimination of organized crime and criminal cases, as well as on the protection of property, economic rights and life of citizens from criminality.

9) Involvement of international organizations specializing in counteraction to illegal economic activity.

10) Introducing in the legislation administrative fines and criminal liability to entrepreneurs who try to evade taxes or engage in illegal activities.

Realization of these measures will allow to significantly reduce the share of the shadow sector in the economy of our state. Only well-defined strategic goals and the right tactics chosen by management will be able to provide us with a long-awaited success. 


\section{REFERENCES}

1. Pyrnikoza PV Prychyny znachnyh obsiagiv tiniovoi ekonomiky v Ukraini ta shliakhy ih usunennia: fiskalni aspekty [Reasons for significant volumes of the shadow economy in Ukraine and ways to eliminate them: fiscal aspects] [Electronic resource] Access to resource: http://www.economy.nayka.com.ua/?op=1\&z=4918

2. Orlyk OV Analiz faktoriv vplyvu na ekonomichnu bezpeku pidpryemnytstva ta matody zahystu vid zagroz I neitralizatsii ih naslidkiv [Analysis of factors affecting the economic security of enterprises and methods for protecting against threats and neutralizing their consequences] [Electronic resource] Access to resourse: http://dspace.oneu.edu.ua/jspui/bitstream/123456789/2996/1/ Аналіз\%20факторів\%20впливу\%20на\%20економічну\%20безпеку\%20підприємств\%20та\%20методи\%20захисту $\% 20$ від\%20загроз\%20i\%20нейтралізації\%20їх\%20наслідків.pdf

3. Belous GV, Yurchik IB Detinizatsiia tiniovoi ekonomiky [Deconstruction of the national economy] [Electronic resource] Access to resource: http://intkonf.org/bilous-gv-yurchik-ibdetinizatsiya-natsionalnoyi-ekonomiki/

4. Shnayder F Tiniova ekonomika: prychyny rostu I naslidky [Shadow economics: the essence, causes, ways of solving]/ F. Shnayder, D. Enste // 2001. - Argumenty fakty. [Shadow economy: the size, causes and consequences of growth] - №17. - R. 6.

5. Pylypchenko OO (2016) Tiniova ekonomika v Ukraini: prychyny, metody vymiriuvannia ta factory negatyvnoi dii na ekonomichnu bezpeku [Shadow economy in Ukraine: causes, measurement methods and factors of negative impact on economic security] - p.28-29.

6. Svitovyi bank [World Bank] [Electronic Resource] - Access to resourse: https://www.worldbank.org.

7. Derzhavna sluzhba statystyky Ukrainy [State Statistics Service of Ukraine] [Electronic resource] - Access to resource: https://www.ukrstat.gov.ua.

8. Ministerstvo ekonomichnogo rozvytku I torgivli Ukrainy [Ministry of Economic Development and Trade of Ukraine] [Electronic resource] - Access to resource: http://www.me.gov.ua.

9. Bambindra DI, Cherep OG, Ovcharenko AV (2014) Tiniova ekonomika iak problema integratsiinoi vzaemodii gospodariuiuchyh subektiv [Shadow economy as a problem of integration interaction of economic entities] - P. 39-42.

10. Baranov SO (2015). Tiniova ekonomika: sutnist, prychyny, sotsialno-ekonomichni naslidky ta shliakhy podolannia $\mathrm{v}$ Ukraini [Shadow economy: the essence, causes, socioeconomic consequences and ways of overcoming in Ukraine]P. 47-54.

11. Schneider, Friedrich, Buehn, Andreas and Montenegro, Claudio E. (2010). New Estimates for the Shadow Economies all over the World ', International Economic Journal, 24: 4, 443-461.

12. Ukraina posidae trete mistse $\mathrm{v}$ reityngu krain iz naibilshym obsiagom tiniovoi ekonomiky - doslidzhennia [Ukraine ranks third in the ranking of countries with the largest amount of shadow economy - research] [Electronic resource] - Access to research: http://gordonua.com/ukr/news/politics/-ukrajinazajmaje-tretje-mistse-vrejtingu-krajin $\quad$-z-najbilshimobsjagom-tinovoji-ekonomiki-doslidzhennya-195533.html

13. Tenevaia ekonomika I ekonomicheskaia prestupnost. Masshtaby tenevoi ekonomiki [Shadow economy and economic crime. The scale of the shadow economy] [Electronic resource]. - Access to research: http://polbu.ru/shadow_economy/ch02_all.html

14. https://www.pwc.com/gx/en/paying-taxes-2016/paying-taxes-2015.pdf 